\title{
SISTEM PAKAR DASS-42 UNTUK MENDETEKSI PSIKIS MAHASISWA DIMASA PANDEMI COVID-19 MENGGUNAKAN METODE TOPSIS
}

\author{
Risma Oktaviani ${ }^{1}$, Riffa Haviani Laluma ${ }^{2}$ \\ 1 Teknik Informatika, Fakultas Teknik, Universitas sangga Buana \\ ${ }^{2}$ Teknik Informatika, Fakultas Teknik, Universitas sangga Buana \\ ${ }^{1}$ korespondensi : risma3110@gmail.com
}

\begin{abstract}
During this Covid-19 pandemic, many schools and universities have implemented online learning due to controlling the number of positive cases of Covid-19 which continues to grow. The online learning process which is sometimes carried out less effectively and efficiently causes some students, especially students to have piles of homework that continues to pile up which eventually results in abnormal psychology being suffered. In processing data, the topsis method can calculate data with the type of multi-attribute decision making which makes the data processed with different outputs, so this method was chosen to be used in making this system. The application of an expert system for early identification of student psychological disorders during the Covid-19 pandemic has been created to help the general public with the percentage of eligibility for system testing of $50 \%$ good value, $17 \%$ very good value, $23 \%$ moderate value, and $11 \%$ less value based on the results of the questionnaire.
\end{abstract}

Keywords: Expert System, DASS, TOPSIS

\begin{abstract}
ABSTRAK
Dimasa pandemi Covid-19 ini, banyak sekolah dan perguruan tinggi yang memberlakukan pembelajaran secara daring dikarenakan pengendalian jumlah kasus positif Covid-19 yang terus bertambah. Proses pembelajaran daring yang terkadang dilakukan dengan kurang efektif dan efisien mengakibatkan beberapa pelajar khususnya mahasiswa memiliki tumpukan pekerjaan rumah yang terus bertumpuk yang akhirnya mengakibatkan adanya psikologi abnormal yang diderita. Dalam melakukan pengolahan data, metode topsis dapat menghitung data dengan jenis multiattribute decision making yang membuat data diolah dengan output yang berbeda-beda, sehingga metode ini dipilih untuk digunakan dalam pembuatan sistem ini. Aplikasi sistem pakar identifikasi dini gangguan psikologis mahasiswa pada masa pandemi Covid-19 ini telah dibuat untuk membantu masyarakat umum dengan persentasi kelayakan pengujian sistem $50 \%$ bernilai baik, $17 \%$ bernilai sangat baik, $23 \%$ bernilai cukup, dan $11 \%$ bernilai kurang berdasarkan hasil kuisioner.
\end{abstract}

Kata kunci: sistem pakar, DASS, TOPSIS

\section{PENDAHULUAN}

Pada saat ini, di dunia khususnya Indonesia telah terjadi penyebaran virus covid-19 yang sedang marak-maraknya. Virus tersebut merupakan sebuah penyakit menular yang memiliki kecepatan penularan yang sangat tinggi khususnya di Indonesia. Menurut Kementrian Kesehatan, wabah ini bisa menular melalui tetesan kecil (droplet) dari hidung atau mulut pada saat batuk atau bersin.
Dikarenakan sifat penyakit yang memiliki nilai penularan yang sangat tinggi, maka pemerintah Indonesia mengambil keputusan untuk menjalankan Pembatasan Sosial Berskala Besar (PSBB) dibeberapa daerah atau wilayah yang memiliki tingkat penyebaran yang tinggi yang mengakibatkan seluruh lembaga Pendidikan ditutup, dan sebagai gantinya, lembaga pendidikan mulai menerapkan sistem e-learning atau pembelajaran daring. 
Pembelajaran adalah suatu sistem, yang didalamnya terdapat interaksi antara berbagai elemen sistem pendidikan, antara lain siswa/peserta didik, pendidik/guru/instruktur, sumber/bahan ajar, dan konteks belajar yang mendukung proses tersebut. Jika semua elemen tersebut dilaksanakan dengan baik melalui sistem pengelolaan pembelajaran sesuai dengan standar yang sudah diatur maka keberhasilan proses pembelajaran akan tercapai. Saat menerapkan pembelajaran daring, pengelolaan pembelajaran harus dipastikan sesuai dengan landasan-landasan yang telau disebutkan diatas untuk mencapai keefektifan belajar siswa[1].

Penerapan pembelajaran secara daring dinilai tidak maksimal dan menunjukan masih ada ketidak siapan dikalangan pendidik untuk beradaptasi diiklim digital meskipun telah diterapkan dengan berbagai cara oleh pengajar di saat penutupan sekolah dilaksanakan untuk mengantisipasi coronavirus [2].

Banyak lembaga pendidikan yang mempergunakan metode pemberian tugas secara daring bagi para pelajar. Dalam keadaan darurat coronavirus saat ini, jenis penugasan pekerjaan rumah dianggap efektif untuk pembelajaran jarak jauh. Hal ini menyebabkan pengenalan konsep pembelajaran, dan penerapannya pada pembelajaran tatap muka tidak dapat berjalan dengan baik [2].

Kegagapan pendidik, kebingungan orang tua selaku pendamping kegiatan belajar dirumah dan kebingungan pelajar tentang metode pembelajaran online tak luput dengan banyaknya tugas yang menumpuk menyebabkan tekanan psikologis yang lebih luas, terutama selama pandemi coronavirus. Harga konsultasi medis yang terbilang cukup mahal serta banyak orang tua yang berfikir bahwa kondisi mental anak-anak mereka dapat diperbaiki sendiri tanpa harus menemui ahlinya. Selain itu, tempat praktik yang tidak selalu tersedia di tiap daerah pun menjadi alasan kenapa orang-orang enggan untuk memeriksakannya. Awamnya para orang tua tentang kesadaran mental atau psikis anak, kadang mengakibatkan ketidak sadaran bahwa anak mengalami masalah psikis yang semakin lama semakin memburuk jika tidak ditangani dengan segera.

Sistem pakar dikenal juga dengan nama knowledge based system, adalah aplikasi komputer yang dirancang untuk membantu pengambilan keputusan atau pemecahan masalah dalam bidang tertentu. Sistem ini menggunakan tenaga ahli untuk bekerja berdasarkan pengetahuan dan metode analisis yang telah ditentukan sebelumnya di bidang keahliannya [3].

Sistem pakar merupakan sebuah sistem yang menggunakan sistem kecerdasan buatan. Secara umum, sistem pakar adalah suatu sistem yang dapat menyamai pengetahuan para ahli atau seorang pakar. Sistem ini menerapkan pengetahuan, fakta, dan teknik penalaran untuk mengatasi masalah yang umumnya hanya dapat dilakukan oleh seorang pakar.

Oleh karena itu, dalam penulisan penelitian ini akan dibuat sebuah sistem pakar untuk mendiagnosis kondisi psikis pelajar dalam 
menghadapi atau selama masa pembelajaran daring berbasis web.

Terdapat berbagai macam metode yang bisa digunakan untuk sistem pakar, salah satunya adalah Topsis. Topsis ini sendiri mengambil keputusan berdasarkan dari kriteria-kriteria yang jumlahnya tidak sedikit.

\section{TINJAUAN PUSTAKA}

\section{Sistem Pakar}

Sistem pakar adalah sebuah program komputer yang mencoba merepetisi pengetahuan dan kapabilitas dari seorang pakar tertentu. Lalu dilangkah selanjutnya, sistem ini akan mencoba memecahkan masalah berdasarkan data yang didapat dari pakar [4]. Keterampilan tersebut dikembangkan dari pelatihan dan pengalaman. Terkadang, pengetahuan ini disebut dengan shallow knowledge karena terdiri dari semua heuristic dan alternatif khusus yang telah dipelajari oleh para professional terlatih untuk digunakan agar menghasilkan kinerja yang lebih baik [5].

\section{Psikologi Abnormal atau kelainan Psikologi}

Psikologi abnormal mencakup semua bentuk gangguan kelainan jiwa baik dalam konten tentang apa saja yang abnormal maupun dalam proses tentang penyebab, gejala, dan konsekuensi dari gangguan tersebut [6].

Beberapa psikologi abnormal yang digunakan dalam penelitian ini adalah sebagai berikut:

a. Stress

$\begin{array}{lcr}\text { Stress adalah inefisiensi atau } & \begin{array}{r}\text { atam } \\ \text { ketidakmampuan }\end{array}\end{array}$

mengatasi ancaman yang sedang dan atau akan dihadapi oleh mental, fisik, emosional dan spiritual manusia yang pada akhirnya dapat mempengaruhi kondisi fisik atau kesehatan pribadi seseorang [7].

b. Gangguan Kecemasan

Gangguan kecemasan adalah suatu kondisi risau yang merasa bahwa sesuatu yang buruk akan terjadi, hal tersebut merupakan respon yang terjadi terhadap ancaman. Apabila kadar atau kapasitasnya tidak sesuai dengan perasaan seharusnya atau perasaan risau dan cemas yang dating tanpa tahu berasal dari mana dengan alasan yang tidak atau kurang jelas[8].

c. Depresi

Depresi berawal dari stress yang tidak diatasi, maka seseorang akan berlanjut ke fase depresi. Ini adalah gangguan mood yang diidentifikasi dengan hilangnya minat dan kegembiraan disertai dengan gejala-gejala lain [9].

\section{METODE}

TOPSIS dikemukakan oleh Yoon \& Hwang pada tahun 1981 dan digunakan sebagai metode untuk menyelesaikan permasalahan berbagai ragam kriteria [10]. TOPSIS memberikan berbagai kemungkinan alternatif dengan mempertimbangkan seluruh alternatif dengan alternatif terburuk dan terbaik. Metode ini menggunakan kesenjangan untuk perbandingan [10].

TOPSIS adalah metode multikriteria yang digunakan untuk meminimalkan jarak ke titik terendah sambil mengidentifikasi solusi dari sekumpulan kandidat. TOPSIS dapat 
menggabungkan bobot relatif dari kriteria penting. Langkah Langkah metode TOPSIS adalah sebagai berikut [11].

1. Menentukan matriks keputusan yang akan dinormalisasi (R), seperti persamaan 1.

$$
r_{i j}=\frac{x_{i j}}{\sqrt{\sum_{j=1^{m} x_{j j}^{2}}^{2}}}(i=1,2, \ldots, n ; j=1,2, \ldots, m)
$$

Keterangan:

$\mathrm{X}_{\mathrm{ij}}$ merupakan rating kinerja alternatif ke-I terhadap atribut $\mathrm{j}$

$\mathrm{R}_{\mathrm{ij}}$ adalah elemen dari matriks keputusan yang ternormalisasi

2. Menentukan matriks keputusan yang terbobot $(\mathrm{Y})$, seperti pesamaan 2.

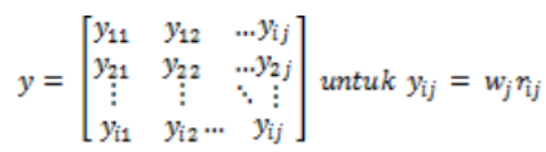

Keterangan:

$\mathrm{W}_{\mathrm{j}}$ adalah bobot kriteria ke- $\mathrm{j}$

$\mathrm{U}_{\mathrm{ij}}$ adalah elemen dari matriks keputusan yang ternormalisasi terbobot

3. Menentukan matriks solusi ideal positif (A+) dari matriks solusi ideal negatif (A-), seperti pada persamaan 3 dan 4 .

$$
\begin{aligned}
& \mathrm{A}^{+}=\left(\mathrm{y}_{1}{ }^{+}, \mathrm{y}_{2}^{+}, \ldots, \mathrm{y}_{\mathrm{j}}^{+}\right) \\
& \mathrm{A}^{-}=\left(\mathrm{y}_{1}-\mathrm{y}_{2}^{-}, \ldots, \mathrm{y}_{\mathrm{j}}^{-}\right)
\end{aligned}
$$

Dengan

$$
\begin{gathered}
y_{j}{ }^{+}=\left\{\begin{array}{c}
\max _{i} y_{i j}, j i k a j=\text { keuntungan } \\
\min _{i} y_{i j}, j i k a j=\text { biaya }
\end{array}\right. \\
y_{j}{ }^{-}=\left\{\begin{array}{c}
\max \\
i \\
\min _{i j}, j i k a j=\text { keuntungan } \\
i
\end{array} y_{i j}, j i k a j=\right.\text { biaya }
\end{gathered}
$$

4. Menentukan jarak nilai alternatif dari matriks solusi ideal positif (di+) dan matriks solusi ideal negatif (di-), jarak solusi ideal positif (di+) seperti persamaan 7.

$$
d_{i}{ }^{+}=\sqrt{\sum_{j=1}^{m}\left(y_{i j}-y_{j}{ }^{+}\right)^{2}}
$$

\section{Keterangan:}

$\mathrm{Y}_{\mathrm{j}+}$ adalah elemen dari matriks solusi ideal positif

Jarak solusi idela negative (di-) seperti persamaan 8 .

$$
d_{i}{ }^{-}=\sqrt{\sum_{j=1}^{m}\left(y_{i j}-y_{j}{ }^{-}\right)^{2}}
$$

\section{Keterangan:}

$\mathrm{Y}_{\mathrm{j}-\text { adalah elemen dari matriks solusi ideal }}$ negatif.

5. Menentukan nilai preferensi (ci) untuk setiap alternatif, nilai preferensi merupakan kedekatan suatu alternatif terhadap solusi ideal, seperti persamaan 9 .

$$
c_{i}=\frac{d_{i}}{d_{i}{ }^{-}+d_{i}{ }^{+}}
$$

Keterangan:

Nilai $c_{i}$ yang lebih besar menunjukan prioritas alternatif

\section{HASIL DAN PEMBAHASAN}

Kelainan pada psikologi ini dapat ditentukan dengan melihat gejala-gejala yang diperoleh dalam Depression Anxiety Stress Scales (DASS 42).

Berikut adalah tabel gejala-gejala untuk kelainan psikologi depresi, kecemasan dan stress dibawah ini. 
Tabel 1 : Gejala Depresi, Kecemasan dan Stress

\begin{tabular}{|c|c|c|}
\hline Kode & Gejala & Bobot \\
\hline $\mathrm{C} 1$ & Tidak dapat merasakan hal positif dari setiap kegiatan & 0,25 \\
\hline $\mathrm{C} 2$ & Merasa tidak sanggup untuk melakukan kegiatan & 0,34 \\
\hline $\mathrm{C} 3$ & Pesimis & 0,35 \\
\hline $\mathrm{C} 4$ & Merasa sedih dan depresi & 0,38 \\
\hline $\mathrm{C} 5$ & Tidak berminat untuk melakukan apapun (belajar, bersosialisasi, makan, dll) & 0,34 \\
\hline C6 & Merasa diri tidak layak & 0,34 \\
\hline $\mathrm{C} 7$ & Merasa hidup tidak berharga & 0,26 \\
\hline $\mathrm{C} 8$ & Tidak bisa menikmati hal-hal yang sedang dilakukan & 0,34 \\
\hline $\mathrm{C} 9$ & Merasa hilang harapan dan putus asa & 0,28 \\
\hline $\mathrm{C} 10$ & Sulit untuk antusias pada banyak hal & 0,36 \\
\hline $\mathrm{C} 11$ & Merasa tidak berharga & 0,26 \\
\hline $\mathrm{C} 12$ & Tidak ada harapan untuk masa depan & 0,20 \\
\hline $\mathrm{C} 13$ & Merasa hidup tidak berarti & 0,21 \\
\hline $\mathrm{C} 14$ & Sulit untuk meningkatkan inisiatif dalam melakukan sesuatu & 0,37 \\
\hline $\mathrm{C} 1$ & Mulut terasa kering & 0,29 \\
\hline $\mathrm{C} 2$ & Bernafas dengan cepat atau dan sulit bernafas & 0,19 \\
\hline $\mathrm{C} 3$ & Mengalami kelemahan pada salah satu anggota tubuh & 0,28 \\
\hline $\mathrm{C} 4$ & Cemas yang berlebihan dalam suatu situasi namun bisa lega jika hal/situasi itu berakhir & 0,44 \\
\hline $\mathrm{C} 5$ & Kelelahan & 0,45 \\
\hline C6 & Berkeringat padahal tidak sedang melakukan kegiatan fisik atau cuaca sedang tidak panas & 0,25 \\
\hline $\mathrm{C} 7$ & Ketakutan tanpa alasan yang jelas & 0,33 \\
\hline $\mathrm{C} 8$ & Kesulitan dalam menelan & 0,10 \\
\hline $\mathrm{C} 9$ & Jantung berdetak kencang saat tidak melakukan apapun contohnya olahraga dll & 0,20 \\
\hline $\mathrm{C} 10$ & Mudah panik & 0,36 \\
\hline $\mathrm{C} 11$ & Tidak gagal karena tidak bisa menyelesaikan tugas-tugas & 0,43 \\
\hline $\mathrm{C} 12$ & Ketakutan yang tidak beralasan & 0,33 \\
\hline $\mathrm{C} 13$ & $\begin{array}{l}\text { Khawatir dengan situasi saat diri anda mungkin menjadi panik dan mempermalukan diri } \\
\text { sendiri }\end{array}$ & 0,38 \\
\hline $\mathrm{C} 14$ & Gemetar & 0,25 \\
\hline $\mathrm{C} 1$ & Menjadi marah karena hal-hal kecil atau sepele & 0,39 \\
\hline $\mathrm{C} 2$ & Cenderung berekasi berlebihan pada situasi & 0,31 \\
\hline $\mathrm{C} 3$ & Kesulitan untuk bersantai / berelaksasi & 0,36 \\
\hline $\mathrm{C} 4$ & Mudah merasa kesal & 0,41 \\
\hline $\mathrm{C} 5$ & Merasa banyak menghabiskan energi karena cemas & 0,37 \\
\hline $\mathrm{C} 6$ & Tidak Sabaran & 0,37 \\
\hline $\mathrm{C} 7$ & Mudah tersinggung & 0,34 \\
\hline $\mathrm{C} 8$ & Sulit untuk beristirahat & 0,37 \\
\hline $\mathrm{C} 9$ & Mudah marah & 0,36 \\
\hline $\mathrm{C} 10$ & Kesulitan untuk tenang setelah sesuatu yang mengganggu & 0,39 \\
\hline $\mathrm{C} 11$ & Sulit mentoleransi gangguan gangguan terhadap hal yang sedang dilakukan & 0,33 \\
\hline $\mathrm{C} 12$ & Selalu merasa tegang & 0,28 \\
\hline $\mathrm{C} 13$ & Marah terhadap hal-hal yang dianggap menghalangi kegiatan atau pekerjaan & 0,25 \\
\hline $\mathrm{C} 14$ & Mudah gelisah & 0,35 \\
\hline
\end{tabular}


Ketarangan :

Kuning : Gejala Depresi

Biru : Gejala Kecemasan

Hijau : Gejala Stress

1. Penerapan Metode Topsis

Nilai perhitungan Topsis ini diambil dari

peserta pertama yang mengisi Kuisioner yang sudah disebarkan terlebih dahulu. Yang harus dilakukan adalah menentukan nilai yang akan dihitung.

\section{Tabel 2 : Tabel Nilai Seorang Pasien}

\begin{tabular}{|c|c|c|}
\hline Kode & Gejala & Bobot \\
\hline $\mathrm{C} 1$ & Tidak dapat merasakan hal positif dari setiap kegiatan & 2 \\
\hline $\mathrm{C} 2$ & Merasa tidak sanggup untuk melakukan kegiatan & 3 \\
\hline $\mathrm{C} 3$ & Pesimis & 1 \\
\hline $\mathrm{C} 4$ & Merasa sedih dan depresi & 2 \\
\hline $\mathrm{C} 5$ & Tidak berminat untuk melakukan apapun (belajar, bersosialisasi, makan, dll) & 2 \\
\hline $\mathrm{C} 6$ & Merasa diri tidak layak & 1 \\
\hline $\mathrm{C} 7$ & Merasa hidup tidak berharga & 2 \\
\hline $\mathrm{C} 8$ & Tidak bisa menikmati hal-hal yang sedang dilakukan & 2 \\
\hline $\mathrm{C} 9$ & Merasa hilang harapan dan putus asa & 2 \\
\hline $\mathrm{C} 10$ & Sulit untuk antusias pada banyak hal & 2 \\
\hline $\mathrm{C} 11$ & Merasa tidak berharga & 0 \\
\hline $\mathrm{C} 12$ & Tidak ada harapan untuk masa depan & 1 \\
\hline $\mathrm{C} 13$ & Merasa hidup tidak berarti & 1 \\
\hline $\mathrm{C} 14$ & Sulit untuk meningkatkan inisiatif dalam melakukan sesuatu & 1 \\
\hline $\mathrm{C} 1$ & Mulut terasa kering & 2 \\
\hline $\mathrm{C} 2$ & Bernafas dengan cepat atau dan sulit bernafas & 2 \\
\hline $\mathrm{C} 3$ & Mengalami kelemahan pada salah satu anggota tubuh & 0 \\
\hline $\mathrm{C} 4$ & Cemas yang berlebihan dalam suatu situasi namun bisa lega jika hal/situasi itu berakhir & 2 \\
\hline $\mathrm{C} 5$ & Kelelahan & 3 \\
\hline C6 & Berkeringat padahal tidak sedang melakukan kegiatan fisik atau cuaca sedang tidak panas & 2 \\
\hline $\mathrm{C} 7$ & Ketakutan tanpa alasan yang jelas & 1 \\
\hline $\mathrm{C} 8$ & Kesulitan dalam menelan & 2 \\
\hline $\mathrm{C} 9$ & Jantung berdetak kencang saat tidak melakukan apapun contohnya olahraga dll & 1 \\
\hline $\mathrm{C} 10$ & Mudah panik & 2 \\
\hline $\mathrm{C} 11$ & Tidak gagal karena tidak bisa menyelesaikan tugas-tugas & 2 \\
\hline $\mathrm{C} 12$ & Ketakutan yang tidak beralasan & 2 \\
\hline $\mathrm{C} 13$ & $\begin{array}{l}\text { Khawatir dengan situasi saat diri anda mungkin menjadi panik dan mempermalukan diri } \\
\text { sendiri }\end{array}$ & 2 \\
\hline $\mathrm{C} 14$ & Gemetar & 2 \\
\hline $\mathrm{C} 1$ & Menjadi marah karena hal-hal kecil atau sepele & 2 \\
\hline $\mathrm{C} 2$ & Cenderung berekasi berlebihan pada situasi & 1 \\
\hline $\mathrm{C} 3$ & Kesulitan untuk bersantai / berelaksasi & 1 \\
\hline $\mathrm{C} 4$ & Mudah merasa kesal & 3 \\
\hline $\mathrm{C} 5$ & Merasa banyak menghabiskan energi karena cemas & 0 \\
\hline C6 & Tidak Sabaran & 2 \\
\hline $\mathrm{C} 7$ & Mudah tersinggung & 1 \\
\hline $\mathrm{C} 8$ & Sulit untuk beristirahat & 2 \\
\hline
\end{tabular}




\begin{tabular}{|c|l|c|}
\hline Kode & \multicolumn{1}{|c|}{ Gejala } & Bobot \\
\hline C9 & Mudah marah & 2 \\
\hline C10 & Kesulitan untuk tenang setelah sesuatu yang mengganggu & 2 \\
\hline C11 & Sulit mentoleransi gangguan gangguan terhadap hal yang sedang dilakukan & 2 \\
\hline C12 & Selalu merasa tegang & 2 \\
\hline C13 & Marah terhadap hal-hal yang dianggap menghalangi kegiatan atau pekerjaan & 1 \\
\hline C14 & Mudah gelisah & 1 \\
\hline
\end{tabular}

2. Masukan kedalam tabel agar mudah dimengerti

Tabel 3 : Tabel Nilai Kuisioner

\begin{tabular}{|l|l|l|l|l|l|l|l|l|l|l|l|l|l|l|}
\hline & C1 & C2 & C3 & C4 & C5 & C6 & C7 & C8 & C9 & C10 & C11 & C12 & C13 & C14 \\
\hline & C1 & C2 & C3 & C4 & C5 & C6 & C7 & C8 & C9 & C10 & C11 & C12 & C13 & C14 \\
\hline & C1 & C2 & C3 & C4 & C5 & C6 & C7 & C8 & C9 & C10 & C11 & C12 & C13 & C14 \\
\hline P1 & 2 & 3 & 1 & 2 & 2 & 1 & 2 & 2 & 2 & 2 & 0 & 1 & 1 & 1 \\
\hline P2 & 2 & 2 & 0 & 2 & 3 & 2 & 1 & 2 & 1 & 2 & 2 & 2 & 2 & 2 \\
\hline P3 & 2 & 1 & 1 & 3 & 0 & 2 & 1 & 2 & 2 & 2 & 2 & 2 & 1 & 1 \\
\hline
\end{tabular}

3. Matriks Ternormalisasi

Tabel 4 : Tabel Pemabgi Matriks Ternormalisasi

\begin{tabular}{|l|l|l|l|l|l|l|l|l|l|l|l|l|l|l|}
\hline & C1 & C2 & C3 & C4 & C5 & C6 & C7 & C8 & C9 & C10 & C11 & C12 & C13 & C14 \\
\hline & C1 & C2 & C3 & C4 & C5 & C6 & C7 & C8 & C9 & C10 & C11 & C12 & C13 & C14 \\
\hline & C1 & C2 & C3 & C4 & C5 & C6 & C7 & C8 & C9 & C10 & C11 & C12 & C13 & C14 \\
\hline Pembagi & 3,46 & 3,742 & 1,41 & 4,12 & 3,61 & 3 & 2,45 & 3,46 & 3 & 3,46 & 2,83 & 3 & 2,45 & 2,45 \\
\hline
\end{tabular}

Mencari nilai pembagi untuk matriks ternormalisasi.

Tabel 5 : Tabel Ternormalisasi

\begin{tabular}{|l|l|l|l|l|l|l|l|l|l|l|l|l|l|l|}
\hline & C1 & C2 & C3 & C4 & C5 & C6 & C7 & C8 & C9 & C10 & C11 & C12 & C13 & C14 \\
\hline & C1 & C2 & C3 & C4 & C5 & C6 & C7 & C8 & C9 & C10 & C11 & C12 & C13 & C14 \\
\hline & C1 & C2 & C3 & C4 & C5 & C6 & C7 & C8 & C9 & C10 & C11 & C12 & C13 & C14 \\
\hline P1 & 0,58 & 0,80 & 0,71 & 0,49 & 0,55 & 0,33 & 0,82 & 0,58 & 0,67 & 0,58 & 0,00 & 0,33 & 0,41 & 0,41 \\
\hline P2 & 0,58 & 0,53 & 0,00 & 0,49 & 0,83 & 0,67 & 0,41 & 0,58 & 0,33 & 0,58 & 0,71 & 0,67 & 0,82 & 0,82 \\
\hline P3 & 0,58 & 0,27 & 0,71 & 0,73 & 0,00 & 0,67 & 0,41 & 0,58 & 0,67 & 0,58 & 0,71 & 0,67 & 0,41 & 0,41 \\
\hline
\end{tabular}

4. Bobot Ternormalisasi

Tabel 6 : Tabel Bobot Ternormalisasi

\begin{tabular}{|l|l|l|l|l|l|l|l|l|l|l|l|l|l|l|}
\hline & 0,25 & 0,34 & 0,35 & 0,38 & 0,34 & 0,34 & 0,26 & 0,34 & 0,28 & 0,36 & 0,26 & 0,20 & 0,21 & 0,37 \\
\hline & 0,29 & 0,19 & 0,28 & 0,44 & 0,45 & 0,25 & 0,33 & 0,10 & 0,20 & 0,36 & 0,43 & 0,33 & 0,38 & 0,25 \\
\hline & 0,39 & 0,31 & 0,36 & 0,41 & 0,37 & 0,37 & 0,34 & 0,37 & 0,36 & 0,39 & 0,33 & 0,28 & 0,25 & 0,35 \\
\hline P1 & 0,15 & 0,27 & 0,25 & 0,18 & 0,19 & 0,11 & 0,21 & 0,20 & 0,19 & 0,21 & 0,00 & 0,07 & 0,09 & 0,15 \\
\hline P2 & 0,17 & 0,10 & 0,00 & 0,21 & 0,38 & 0,17 & 0,14 & 0,06 & 0,07 & 0,21 & 0,31 & 0,22 & 0,31 & 0,20 \\
\hline P3 & 0,23 & 0,08 & 0,25 & 0,30 & 0,00 & 0,24 & 0,14 & 0,21 & 0,24 & 0,23 & 0,24 & 0,18 & 0,10 & 0,14 \\
\hline
\end{tabular}

5. Nilai $\mathrm{Y}+$ dan $\mathrm{Y}-$

Tabel 7 : Tabel Nilai Y+ dan Y-

\begin{tabular}{|l|l|l|l|l|l|l|l|l|l|l|l|l|l|l|}
\hline & C1 & C2 & C3 & C4 & C5 & C6 & C7 & C8 & C9 & C10 & C11 & C12 & C13 & C14 \\
\hline & C1 & C2 & C3 & C4 & C5 & C6 & C7 & C8 & C9 & C10 & C11 & C12 & C13 & C14 \\
\hline & C1 & C2 & C3 & C4 & C5 & C6 & C7 & C8 & C9 & C10 & C11 & C12 & C13 & C14 \\
\hline Y+ & 0,23 & 0,27 & 0,25 & 0,30 & 0,38 & 0,24 & 0,21 & 0,21 & 0,24 & 0,23 & 0,31 & 0,22 & 0,31 & 0,20 \\
\hline Y- & 0,15 & 0,08 & 0,00 & 0,18 & 0,00 & 0,11 & 0,14 & 0,06 & 0,07 & 0,21 & 0,00 & 0,07 & 0,09 & 0,14 \\
\hline
\end{tabular}

6. Nilai D+ dan D-

Tabel 8 : Tabel Nilai D+ dan D-

\begin{tabular}{|l|l|l|}
\cline { 2 - 3 } \multicolumn{1}{c|}{} & D+ & D- \\
\hline P1 & 0,498 & 0,415 \\
\hline P2 & 0,415 & 0,564 \\
\hline P3 & 0,487 & 0,475 \\
\hline
\end{tabular}


7. Hasil Akhir

Tabel 9. Hasil Akhir

\begin{tabular}{|r|r|r|c|}
\cline { 2 - 3 } \multicolumn{1}{c|}{} & \multicolumn{1}{c|}{ Nilai } & ranking & Hasil diagnosa \\
\hline P1 & 0,455 & 3 & \multirow{2}{*}{ Kecemasan } \\
\hline P2 & 0,576 & 1 & \\
\hline P3 & 0,494 & 2 & \\
\hline
\end{tabular}

8. Hasil dari Implementasi Sistem

a. Tampilan Form Menu Utama

Pada tampilan ini, halaman

Didalamnya terdapat menu untuk

menunjukan menu menu sistem pakar

mengelola akun dan untuk

yang akan digunakan oleh pengguna.

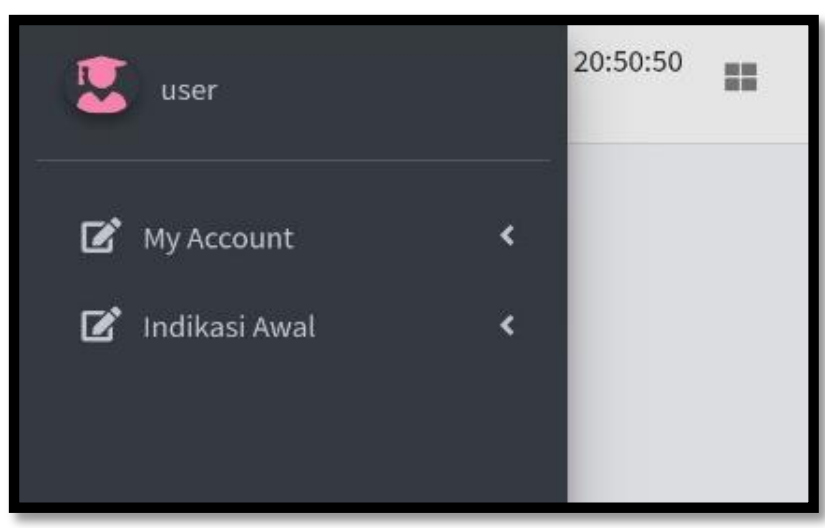

Gambar 1 : Tampilan menu utama

b. Tampilan indikasi penyakit

Pada tampilan ini, user mengisi pertanyaan-pertanyaan yang disediakan oleh sistem sebanyak 42 pertanyaan.



Gambar 2 : Tampilan indikasi penyakit 
c. Tampilan Hasil Akhir

Pada tampilan ini, sistem akan menngindikasi dan menampilkan penyakit apa yang memiliki kemungkinan paling besar dimiliki oleh user. Berikut merupakan contoh dari hasil indikasi.

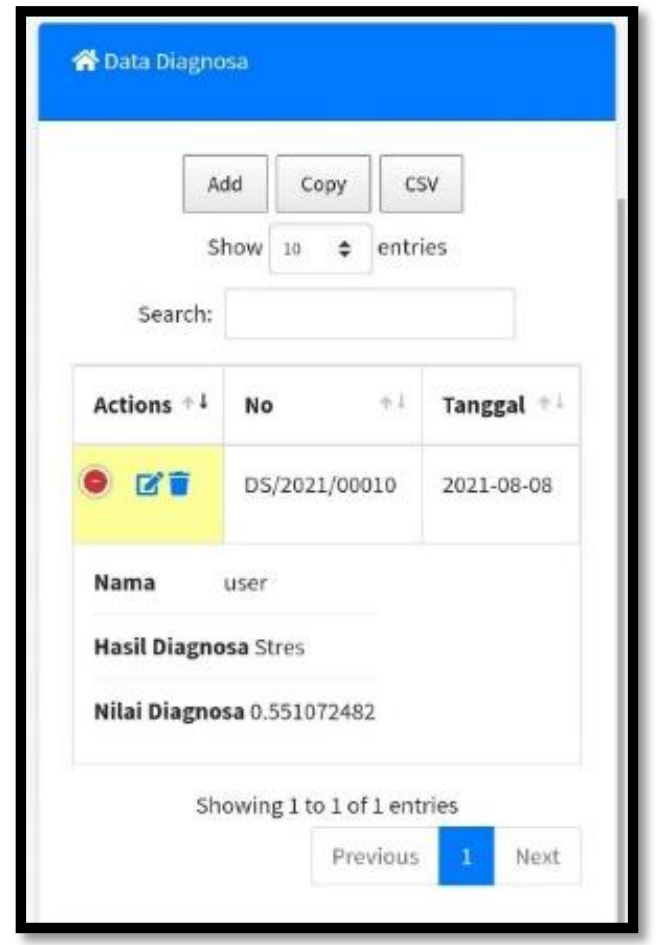

Gambar 3 : Tampilan Hasil Indikasi

\section{KESIMPULAN}

Kesimpulan yang didapat dari pembangunan sistem pengindikasian psikis mahasiswa/i dalam menghadapi pembelajaran daring dimasa pandemi Covid-19 adalah sebagai berikut:

1. Aplikasi pengindikasian psikis pelajar dalam menghadapi pembelajaran daring dimasa pandemi Covid-19 berhasil dibuat dengan berbasis android untuk membantu mahasiswa/mahasiswi dalam mengindikasi psikis.

2. Metode topsis berhasil diterapkan untuk mengetahui penyakit mana yang lebih berpotensi dimiliki oleh seseorang, sehingga pengguna bisa fokus pada satu penyakit itu untuk ditangani lebih lanjut.
3. Apliaksi sistem pakar telah berhasil menghasilkan diagnosis yang sesui dengan pakar atau ahli dibidang penyakit psikologis. Dengan presentasi pengujian layak sebesar 50\% dengan responden medis dan mahasiswa.

\section{DAFTAR PUSTAKA}

[1] M. Yuliani et al., Pembelajaran Daring untuk Pendidikan: Teori dan Penerapan. Yayasan Kita Menulis, 2020.

[2] U. Hasanah, Ludiana, Immawati, and L. PH, "Gambaran Psikologis Mahasiswa Dalam Proses Pembelajaran Selama Pandemi Covid19," J. Keperawatan Jiwa, vol. 8, no. 3, pp. 299-306, 2020, [Online]. Available:

https://jurnal.unimus.ac.id/index.php/J $\mathrm{KJ} /$ article/view/5941.

[3] B. H. Hayadi, Sistem Pakar. 
Deepublish, 2018.

[4] J. Irawan, "Buku Pegangan Kuliah Sistem Pakar," Sekol. Tinggi Manaj. Inform. Tek. Komput. Surabaya, no. July, 2007, [Online]. Available: http://prints.upnyk.ac.id/774/3/6 Abstrak.pdf.

[5] M. Klein and L. B. Methlie, Expert systems: A decision support approach: With applications in management and finance. Addison-Wesley, 1990.

[6] D. Kuntjojo and M. Pd, "Psikologi Abnormal Www.Psikoterapis.Com," 2009.

[7] I. E. Indira, "Stress Questionnaire: Stress Investigation From Dermatologist Perspective," Psychoneuroimmunology

Dermatology, pp. 141-142, 2016.
[8] A. Marheni, "Bahan Ajar Psikologi Abnormal," הנוטע עלון, vol. 66, pp. 3739, 2016

[9] D. R. N. Lumongga, Depresi: tinjauan psikologis. Kencana, 2016.

[10] M. K. Marbun, Murni S.Si., MM. and M. K. Sinaga, Bosker S, Kom.., Buku Ajar Sistem Pendukung Keputusan Penilaian Hasil Belajar | 1 STMIK Pelita Nusantara Medan. 2019.

[11] A. A. Chamid, "Penerapan Metode Topsis Untuk Menentukan Prioritas Kondisi Rumah," Simetris J. Tek. Mesin, Elektro dan Ilmu Komput., vol. 7, no. 2, p. 537, 2016, doi: 10.24176/simet.v7i2.765. 